\title{
Efficacy of Herbicides When Spray Solution Application Is Delayed
}

\author{
Peter M. Eure, David L. Jordan, Loren R. Fisher, and Alan C. York \\ Department of Crop Science, North Carolina State University, P.O. Box 7620, Raleigh, NC 27695-7620, USA \\ Correspondence should be addressed to David L. Jordan; david_jordan@ncsu.edu
}

Received 19 January 2013; Revised 25 May 2013; Accepted 30 May 2013

Academic Editor: Robert J. Kremer

Copyright ( 2013 Peter M. Eure et al. This is an open access article distributed under the Creative Commons Attribution License, which permits unrestricted use, distribution, and reproduction in any medium, provided the original work is properly cited.

\begin{abstract}
Information is limited concerning the impact of delaying applications of pesticides after solution preparation on efficacy. Experiments were conducted to determine weed control when diclosulam, dimethenamid- $P$, flumioxazin, fomesafen, imazethapyr, pendimethalin, and $S$-metolachlor were applied preemergence the day of solution preparation or 3, 6, and 9 days after solution preparation. Herbicide solutions were applied on the same day regardless of when prepared. Control of broadleaf signalgrass, common lambsquarters, entireleaf morningglory, and Palmer amaranth by these herbicides was not reduced regardless of when herbicide solutions were prepared. Surprisingly entireleaf morningglory control by all herbicides increased when herbicide application was delayed by 9 days. In separate experiments, control of broadleaf signalgrass by clethodim, common ragweed by glyphosate and lactofen, entireleaf morningglory by lactofen, Italian rye grass by glyphosate and paraquat, and Palmer amaranth by atrazine, dicamba, glufosinate, glyphosate, imazethapyr, lactofen, and 2,4-D was affected more by increase in weed size due to delayed application than the time between solution preparation and application.
\end{abstract}

\section{Introduction}

Unforeseen circumstances such as high wind speed, excessive rain, and equipment failure may prevent timely application of spray solutions. Spray water quality has been shown to reduce efficacy of glyphosate and other herbicides applied postemergence [1-6]. The greater the length of time the herbicide is in solution the greater the possibility of interactions among constituents in the aqueous carrier [7, 8]. Ammonium sulfate as a spray conditioner prior to adding glyphosate or other herbicides to the solution can minimize adverse effects of polyvalent compounds on herbicide absorption and subsequent efficacy [9-13]. The amount of time between solution preparation and application may increase the time herbicides and polyvalent cations can interact and possibly affect weed control [8].

Efficacy may be affected when pesticides remain in spray solutions for extended periods of time. Permethrin left in municipality ultra-low volume spray tanks for 4 months averaged $55.5 \%$ degradation of the product when analyzed by gas chromatography [14]. In cotton (Gossypium hirsutum L.), performance of ethephon, indoxacarb, methomyl, spinosad, and thidiazuron was influenced when spray solution application was delayed 1 or more days, whereas efficacy of acephate, carfentrazone, diuron plus thidiazuron, ethephon plus cyclanilide, indoxacarb, lambda-cyhalothrin, lambdacyhalothrin plus thiamethoxam, methomyl, thidiazuron, and thiodicarb was not affected when left in spray solution for up to 9 days [15]. In peanut (Arachis hypogaea L.), efficacy was not compromised when the fungicides boscalid, chlorothalonil, fluazinam, prothioconazole plus tebuconazole, pyraclostrobin, and tebuconazole or the plant growth regulator prohexadione calcium remained in spray solution for up to 9 days before application [16]. Efficacy of the plant growth regulators $\mathrm{C}_{8}-\mathrm{C}_{10}$ fatty alcohol, flumetralin, flumetralin plus maleic hydrazide, and maleic hydrazide and the ripening agent ethephon was not affected when spray solutions were prepared up to 7 days before application to tobacco (Nicotiana tabacum L.) [17].

Stewart et al. [18] reported no decrease in control of common ragweed (Ambrosia artemisiifolia L.), common lambsquarters (Chenopodium album L.), redroot pigweed (Amaranthus retroflexus $\mathrm{L}$.), and velvetleaf (Abutilon theophrasti Medik.) by postemergence application of dicamba plus 
diflufenzopyr, glufosinate, glyphosate, mesotrione plus atrazine, and nicosulfuron plus rimsulfuron when spray solutions were prepared 3 and 7 days prior to application. Tank mixes of atrazine plus isoxaflutole remaining in spray solution 7 days prior to application controlled common lambsquarters and velvetleaf less than solutions prepared for a shorter interval prior to application [18]. Velvetleaf control by atrazine plus dicamba plus dimethenamid- $P$ remaining in spray solution 3 or 7 days prior to application was lower compared with application following shorter intervals of mixing [18]. Dicamba plus rimsulfuron plus $S$-metolachlor mixed 1, 3, and 7 days prior to application controlled common lambsquarters and velvetleaf less effectively than when mixed 1 day prior to application [18]. With the exception of work by Stewart et al. [18], information in the peer-reviewed literature is not evident relative to the impact of the time interval between solution preparation and application.

When postemergence herbicide applications are delayed, rapid weed growth may occur when environmental conditions are conducive for growth. Weed size has been shown to influence postemergence herbicide efficacy [19-21]. Entireleaf morningglory (Ipomoea hederacea Jacq. var. integriuscula Gray), hemp sesbania (Sesbania exaltata Rydb.), pitted morningglory (Ipomoea lacunosa L.), prickly sida (Sida spinosa L.), sicklepod (Senna obtusifolia L.), and velvetleaf control by glyphosate was greater when weeds had 1 to 3 leaves compared to weeds with four or more leaves [20]. Sicklepod control by imazaquin was greater when applied to one-leaf plants rather than plants with 3 to 5 leaves [21]. Glufosinate applied to 18 to $23 \mathrm{~cm}$ tall Palmer amaranth resulted in $73 \%$ control [22]. However, application of glufosinate to Palmer amaranth $5 \mathrm{~cm}$ tall or less has been documented to give greater than $90 \%$ control [23]. Efficacy of auxinic herbicides may be influenced when growth exceeds the manufacturer's recommendation for weed size when herbicide is applied. For example, control of dogfennel (Eupatorium capillifolium) was dramatically reduced when 2,4-D plus dicamba was applied to $154 \mathrm{~cm}$ tall plants as compared to $38 \mathrm{~cm}$ tall plants [24].

Understanding the potential loss in herbicide efficacy when applications are delayed is important to prevent weed control failures. Therefore, experiments were conducted to determine the influence of delayed applications on efficacy of seven residual soil-applied herbicide spray solutions prepared up to 9 days prior to application. Experiments were also conducted to determine the impact of increased weed size due to delayed application on herbicide efficacy compared with efficacy when application of spray solutions was delayed.

\section{Materials and Methods}

2.1. General Procedures. Field experiments were conducted during 2009 and 2010 in North Carolina at the Central Crops Research Station near Clayton, the Peanut Belt Research Station near Lewiston-Woodville, the Upper Coastal Plain Research Station near Rocky Mount, and an on-farm site near Falcon. Soils at Clayton, Rocky Mount, LewistonWoodville, and Falcon were a Johns sandy loam (fine-loamy over sandy, siliceous, semiactive, thermic Aquic Hapludults), a Norfolk loamy sand (fine-loamy, kaolinitic, thermic Typic
Kandiudults), a Goldsboro sandy loam (fine-loamy, siliceous, subactive, thermic Aquic Paleudults), and an Autryville loamy sand (loamy, siliceous, subactive, thermic Aquic Paleudults), respectively.

Herbicide solutions were prepared in plastic bottles (3 L volume), sealed, and stored in the dark at room temperature. The water solution was from a municipal source in Wake County, NC with pH 6.7; hardness of $31 \mathrm{mg} \mathrm{kg}^{-1}$; and concentrations of boron, calcium, magnesium, and zinc of $0.04,7.3,0$, and $0.06 \mathrm{mg} \mathrm{kg}^{-1}$, respectively. Herbicides were applied using a $\mathrm{CO}_{2}$-pressurized backpack sprayer calibrated to deliver $140 \mathrm{~L} \mathrm{ha}^{-1}$ at $207 \mathrm{kPa}$ with tapered flat-fan nozzles (TeeJet TP11002 flat-fan spray nozzles, Spraying Systems Co., Wheaton, IL 60189, USA). Spray solutions were thoroughly agitated each time a new solution was prepared and immediately prior to application to bring herbicides into solution.

\subsection{Efficacy of Residual Herbicides Applied Preemergence.} Three trials were conducted during 2009 in two separate fields at the Upper Coastal Plain Research Station near Rocky Mount and in one field at the Central Crops Research Station near Clayton and during 2010 in two separate fields at Rocky Mount. Experiments were conducted in tilled fallow areas with uniform populations of weeds. Plot size was 2 by $6 \mathrm{~m}$. Broadleaf signalgrass (Brachiaria platyphylla (Griseb.) Nash.) was present in three trials during 2009 and two trials during 2010. Entireleaf morningglory and Palmer amaranth (Amaranthus palmeri S. Watts) were present in one trial during 2009 and two trials during 2010. Common lambsquarters was present in one trial during both 2009 and 2010.

Treatments included four mixing intervals $(0,3,6$, and 9 days prior to application) and seven preemergence herbicides. A nontreated control was included. Herbicides included diclosulam (Strongarm herbicide, Dow AgroSciences, Indianapolis, IN, USA) at $30 \mathrm{~g} \mathrm{ai} \mathrm{ha}^{-1}$, dimethenamid$P$ (Outlook herbicide, BASF Corporation, Research Triangle Park, NC, USA) at 1,120 $\mathrm{g}_{\text {ai ha }}{ }^{-1}$, flumioxazin (Valor SX herbicide, Valent U.S.A Corporation, Walnut Creek, CA 94596, USA) at $70 \mathrm{~g}$ ai ha $^{-1}$, the sodium salt of fomesafen (Reflex herbicide, Syngenta Crop Protection, Inc. Greensboro, NC, USA) at $280 \mathrm{gaiha}^{-1}$, the ammonia salt of imazethapyr (Pursuit herbicide, BASF Corporation, Research Triangle Park, NC, USA) at $70 \mathrm{~g}$ ai ha $^{-1}$, pendimethalin (Prowl $\mathrm{H}_{2} \mathrm{O}$ herbicide, BASF Corporation, Research Triangle Park, NC, USA) at 1,235 $\mathrm{g}_{\text {ai ha }}{ }^{-1}$, and $S$-metolachlor (Dual II Magnum, Syngenta Crop Protection, Inc. Greensboro, NC, USA) at $1,345 \mathrm{~g}$ ai ha $^{-1}$. All herbicide solutions were applied on the same day to a freshly tilled field regardless of when solutions were prepared to minimize confounding effects of weed germination and emergence and rainfall. Rainfall of at least $0.65 \mathrm{~cm}$ occurred within 11 days after herbicide application in all experiments (data not shown in tables).

Visible estimates of percent control of broadleaf signalgrass, common lambsquarters, entireleaf morningglory, and Palmer amaranth were recorded 6 weeks after treatment using a scale of 0 to 100 , where 0 equals no control and 100 equals complete control [25]. Population reduction, relative to the nontreated control, foliar chlorosis, and necrosis, and 
plant stunting were considered when making the estimates of visible control.

The experimental design was a randomized complete block with treatments replicated four times. Data for percent control of each species were subjected to ANOVA for a seven (herbicide) by four (interval of delayed application) factorial treatment arrangement using the PROC GLM procedure in SAS (SAS v9.1, SAS Institute Inc., Cary, NC, USA). Means of significant main effects and interactions were separated using Fisher's Protected LSD test at $P \leq 0.05$.

2.3. Efficacy of Postemergence Herbicides. Field experiments were conducted during 2009 and 2010 in North Carolina at the Central Crops Research Station near Clayton, the Peanut Belt Research Station near Lewiston-Woodville, the Upper Coastal Plain Research Station near Rocky Mount, and an on-farm site near Falcon. Experiments were conducted in areas with uniform populations of weeds. Plot size was 2 by $4 \mathrm{~m}$.

In separate experiments, control by atrazine (AAtrex herbicide, Syngenta Crop Protection, Inc., Greensboro, NC, USA) at $1,100 \mathrm{gaiha}^{-1}$, clethodim (Select Max herbicide, Valent U.S.A. Corporation, Walnut Creek, CA, USA) at $1,100 \mathrm{~g}$ ai ha ${ }^{-1}$, the dimethylamine salt of dicamba (Clarity herbicide, BASF Corporation, Research Triangle Park, NC, USA) at $\left(280 \mathrm{~g} \mathrm{ae} \mathrm{ha}^{-1}\right)$, glufosinate (Ignite 280 herbicide, Bayer CropScience, Research Triangle Park, NC, USA) at $500 \mathrm{gaiha}^{-1}$, the potassium salt of glyphosate (Roundup WEATHERMAX herbicide, Monsanto Company, St. Louis, MO, USA) at $840 \mathrm{~g} \mathrm{ae} \mathrm{ha}^{-1}$, the ammonia salt of imazethapyr (Pursuit herbicide, BASF Corporation, Research Triangle Park, NC, USA) at $70 \mathrm{~g} \mathrm{ae} \mathrm{ha}^{-1}$, lactofen (Cobra herbicide, Valent U.S.A Corporation, Walnut Creek, CA, USA) at $220 \mathrm{~g} \mathrm{ha}^{-1}$, and paraquat (Gramoxone Inteon herbicide, Syngenta Crop Protection, Inc. Greensboro, NC, USA) at $560 \mathrm{~g} \mathrm{aiha}^{-1}$ was compared. Atrazine and clethodim were applied with crop oil concentrate (Agri-Dex crop oil concentrate, Helena Chemical Company, Collierville, TN, USA) at $1.0 \%(\mathrm{v} / \mathrm{v})$. Imazethapyr, lactofen, and paraquat were applied with nonionic surfactant (Induce adjuvant, Helena Chemical Company, Collierville, TN, USA) at $0.25 \%$ (v/v). Dicamba, glufosinate, and glyphosate were applied without adjuvant. Herbicides were applied when weeds were 8 to $12 \mathrm{~cm}$ in height corresponding to the desired timing for optimal control based on the manufacturer's recommendations. Herbicides were also applied 4 or 8 days after optimum weed size using solutions prepared the day of application or 4 or 8 days prior to application. Weed size increased as application was delayed by approximately $10 \mathrm{~cm}$ for each 4 -day interval. Broadleaf signalgrass control by clethodim; entireleaf morningglory control by lactofen; common ragweed control by glufosinate, glyphosate, and lactofen; Italian ryegrass (Lolium perenne L.) control by glyphosate and paraquat; and Palmer amaranth control by atrazine, dicamba, glufosinate, glyphosate, imazethapyr, lactofen, paraquat, and 2,4-D were evaluated in two separate experiments for each herbicide. Weed species present were not resistant to the herbicide mode of action evaluated in experiments.
Visible estimates of percent weed control were recorded as described previously 4 weeks after each herbicide treatment irrespective of timing of application. In addition to visible estimates of control, above-ground fresh weight of three broadleaf signalgrass, common ragweed, and Palmer amaranth plants representative of plants in each plot was determined 4 weeks after optimum timing of herbicide application.

The experimental design was a randomized complete block with treatments replicated four times. Data for visible estimates of percent weed control and percent reduction in fresh weight were subjected to ANOVA appropriate for the treatment structure using the PROC GLM procedure in SAS (SAS v9.1, SAS Institute Inc., Cary, NC, USA). Means were separated using Fisher's Protected LSD test at $P \leq 0.05$.

\section{Results and Discussion}

3.1. Efficacy of Residual Herbicides Applied Preemergence. Broadleaf signalgrass, common lambsquarters, and Palmer amaranth control was not affected by the main effect of mixing interval or the interaction of experiment by mixing interval. In general, weed control reflected known performance of these herbicides on weeds present in these experiments [2633]. However, entireleaf morningglory control was affected by the main effect of mixing interval. Control of entireleaf morningglory was 59\% when herbicides were applied on the same day of mixing and did not differ compared with mixing $3(64 \%)$ or $6(62 \%)$ days after mixing. However, when herbicides were applied 9 days after mixing, control was higher (68\%) than control obtained when herbicides were applied the same day of mixing (data not shown in tables). While these results were surprising, response was consistent across the 7 herbicides and 3 experiments. Entireleaf morningglory response is perplexing given other weed species were not affected by timing of solution preparation and because response was consistent across herbicide with different modes of action. Additional research is needed in order to substantiate or refute these results and to develop a plausible explanation.

3.2. Efficacy of Postemergence Herbicides. Broadleaf signalgrass control by clethodim was influenced by the interaction of experiment and combination of time of solution preparation and weed size at time of application. Efficacy of clethodim was not affected when spray solution was prepared 4 or 8 days prior to application when comparing within each timing of solution preparation (Table 1). At Rocky Mount in Field 1, broadleaf signalgrass control was $96 \%$ when clethodim was applied at the optimum timing. However, when application was delayed 8 days control was reduced to $88 \%$ to $90 \%$. Similarly, at Rocky Mount in Field 2, control was $94 \%$ when clethodim was applied to broadleaf signalgrass at the optimum size for control while application 8 days later reduced control to 75 to $79 \%$.

Entireleaf morningglory control by lactofen using spray solution prepared 4 or 8 days prior to application was similar to control by spray solution prepared the day of application (Table 1). At Rocky Mount field 1, entireleaf morningglory control was dramatically reduced when lactofen was applied 8 
TABLE 1: Visible estimates of broadleaf signalgrass, entireleaf morningglory, and common ragweed control by clethodim, lactofen, and glyphosate 4 weeks after application at the manufacturer's suggested weed size and 4 and 8 days after this weed size using spray solutions mixed the day of application or 4 or 8 days prior to application ${ }^{\mathrm{a}}$.

\begin{tabular}{|c|c|c|c|c|c|c|c|}
\hline \multirow{5}{*}{$\begin{array}{l}\text { Timing of } \\
\text { application after } \\
\text { optimum weed size }\end{array}$} & \multirow{5}{*}{$\begin{array}{l}\text { Timing of solution } \\
\text { preparation prior to } \\
\text { application }\end{array}$} & \multicolumn{6}{|c|}{ Visible control } \\
\hline & & \multirow{3}{*}{\multicolumn{2}{|c|}{$\begin{array}{c}\text { Broadleaf signalgrass } \\
\text { Clethodim } \\
\text { Rocky Mount }\end{array}$}} & \multirow{3}{*}{\multicolumn{2}{|c|}{$\begin{array}{c}\text { Entireleaf morningglory } \\
\text { Lactofen } \\
\text { Rocky Mount }\end{array}$}} & \multirow{3}{*}{\multicolumn{2}{|c|}{$\begin{array}{l}\text { Common ragweed } \\
\text { Glyphosate } \\
\text { Lewiston-Woodville }\end{array}$}} \\
\hline & & & & & & & \\
\hline & & & & & & & \\
\hline & & Field 1 & Field 2 & Field 1 & Field 2 & Field 1 & Field 2 \\
\hline Days & Days & \multicolumn{6}{|c|}{$\%$} \\
\hline 0 & 0 & $96^{\mathrm{a}}$ & $94^{\mathrm{a}}$ & $90^{\mathrm{a}}$ & $93^{\mathrm{a}}$ & $97^{\mathrm{ab}}$ & $89^{c}$ \\
\hline 4 & 0 & $93^{\mathrm{ab}}$ & $88^{\mathrm{ab}}$ & $84^{\mathrm{a}}$ & $86^{c}$ & $96^{\mathrm{ab}}$ & $95^{\mathrm{ab}}$ \\
\hline 4 & 4 & $94^{\mathrm{ab}}$ & $86^{\mathrm{b}}$ & $85^{\mathrm{a}}$ & $88^{\mathrm{bc}}$ & $98^{\mathrm{a}}$ & $99^{\mathrm{a}}$ \\
\hline 8 & 0 & $90^{\mathrm{bc}}$ & $75^{\mathrm{c}}$ & $58^{\mathrm{b}}$ & $93^{\mathrm{ab}}$ & $86^{b}$ & $88^{\mathrm{c}}$ \\
\hline 8 & 8 & $88^{c}$ & $79^{c}$ & $56^{\mathrm{b}}$ & $98^{\mathrm{a}}$ & $93^{\mathrm{ab}}$ & $91^{\mathrm{bc}}$ \\
\hline
\end{tabular}

${ }^{\mathrm{a}}$ Means within a weed species, herbicide, location, and field combination followed by the same letter are not different at $P \leq 0.05$.

TABLE 2: Visible estimates of common ragweed control by lactofen and Palmer amaranth control by atrazine, imazethapyr, and 2,4-D 4 weeks after application at the manufacturer's suggested weed size and 4 and 8 days after this weed size using spray solutions mixed the day of application or 4 or 8 days prior to application ${ }^{\text {a }}$.

\begin{tabular}{|c|c|c|c|c|c|}
\hline \multirow{3}{*}{$\begin{array}{l}\text { Timing of application after } \\
\text { optimum weed size }\end{array}$} & \multirow{3}{*}{$\begin{array}{l}\text { Timing of solution } \\
\text { preparation prior to } \\
\text { application }\end{array}$} & \multicolumn{4}{|c|}{ Visible control } \\
\hline & & Common ragweed & & Palmer amaranth & \\
\hline & & Lactofen & Atrazine & Imazethapyr & $2,4-\mathrm{D}$ \\
\hline Days & Days & \multicolumn{4}{|c|}{$\%$} \\
\hline 0 & 0 & $97^{\mathrm{a}}$ & $85^{\mathrm{a}}$ & $87^{\mathrm{a}}$ & $92^{\mathrm{a}}$ \\
\hline 4 & 0 & $93^{\mathrm{b}}$ & $79^{\mathrm{ab}}$ & $85^{\mathrm{a}}$ & $89^{\mathrm{a}}$ \\
\hline 4 & 4 & $95^{\mathrm{ab}}$ & $87^{\mathrm{a}}$ & $83^{\mathrm{ab}}$ & $88^{\mathrm{a}}$ \\
\hline 8 & 0 & $97^{\mathrm{a}}$ & $68^{\mathrm{b}}$ & $77^{\mathrm{b}}$ & $77^{\mathrm{b}}$ \\
\hline 8 & 8 & $97^{\mathrm{a}}$ & $68^{\mathrm{b}}$ & $74^{\mathrm{b}}$ & $75^{\mathrm{b}}$ \\
\hline
\end{tabular}

${ }^{\mathrm{a}}$ Means within a weed species and herbicide combination followed by the same letter are not different at $P \leq 0.05$.

The letters ( $a, b, c, a b$, and bc) following the means in the table are used to differentiate between the numbers in terms of statistical differences. Numbers may be different numerically, but if they have the same letter, they are not statistically different because of variation in the biological system.

days past the optimum weed size for control. Entireleaf morningglory control in field 2 was greater than $86 \%$ regardless of weed size. Common ragweed control by glyphosate was not reduced when left in spray solution 4 or 8 days prior to application. However, common ragweed control was reduced when glyphosate was applied 8 days past optimum weed size in one of two experiments. Generally, control of annual grasses and annual broadleaf weeds would be expected to decrease when application is made to larger weeds [1921, 34, 35]. However, environmental conditions and plant stress on the day of herbicide application can influence herbicide performance [36-38]. While results for entireleaf morningglory control in Rocky Mount field 2 were surprising, other undocumented factors could have caused control of larger weeds 8 days after optimal timing to be greater than control of smaller weeds 4 days after optimal timing.

Common ragweed control by lactofen was influenced by timing of solution preparation prior to application (Table 2). Lactofen application at the optimum weed size for control and 8 days past the optimum weed size controlled common ragweed $97 \%$ while control was reduced when lactofen was applied 4 days past the optimum weed size. However, common ragweed control remained greater than $93 \%$ following lactofen applied 4 or 8 days past the optimum weed size for control.

The combined effect of mixing interval and Palmer amaranth size was not affected by experiment but did affect Palmer amaranth control by atrazine, imazethapyr, and 2,4-D (Table 2). As expected, Palmer amaranth control was reduced when the herbicides were applied 8 days past the optimum weed size for control.

Palmer amaranth control by dicamba, glufosinate, and lactofen was influenced by the combination of mixing interval, weed size, and experiment. Efficacy of dicamba and glufosinate was not reduced when left in spray solution for up to 8 days when comparing within application timings (Table 3 ). However, control was reduced when application was made 4 or 8 days past the optimum weed size. Dicamba applied 8 days past the optimum weed size controlled Palmer amaranth 5\% to $20 \%$ less. At Rocky Mount in Field 1, Palmer amaranth control by glufosinate was 13 to 15 percentage points less when applied 8 days past the optimum weed size. However, at Falcon Palmer amaranth control by glufosinate was $80 \%$ or less regardless of application timing. Palmer amaranth 
TABLE 3: Visible estimates of Palmer amaranth control by glyphosate, dicamba, glufosinate, and lactofen 4 weeks after application at the manufacturer's suggested weed size and 4 and 8 days after this weed size using spray solutions mixed the day of application or 4 or 8 days prior to application ${ }^{\mathrm{a}}$.

\begin{tabular}{|c|c|c|c|c|c|c|c|}
\hline \multirow{3}{*}{$\begin{array}{l}\text { Timing of application } \\
\text { after optimum weed } \\
\text { size }\end{array}$} & \multirow{3}{*}{$\begin{array}{l}\text { Timing of solution } \\
\text { preparation prior to } \\
\text { application }\end{array}$} & \multicolumn{6}{|c|}{ Palmer amaranth control } \\
\hline & & \multicolumn{2}{|c|}{$\begin{array}{c}\text { Dicamba } \\
\text { Rocky Mount }\end{array}$} & \multicolumn{2}{|c|}{ Glufosinate } & \multicolumn{2}{|c|}{ Lactofen } \\
\hline & & Field 1 & Field 2 & Rocky Mount & Falcon & Rocky Mount & Falcon \\
\hline Days & Days & \multicolumn{6}{|c|}{$\%$} \\
\hline 0 & 0 & $88^{\mathrm{a}}$ & $89^{a}$ & $86^{\mathrm{a}}$ & $70^{\mathrm{b}}$ & $93^{\mathrm{a}}$ & $67^{\mathrm{a}}$ \\
\hline 4 & 0 & $80^{\mathrm{ab}}$ & $93^{\mathrm{a}}$ & $86^{\mathrm{a}}$ & $75^{\mathrm{ab}}$ & $88^{\mathrm{a}}$ & $67^{\mathrm{a}}$ \\
\hline 4 & 4 & $78^{\mathrm{bc}}$ & $91^{\mathrm{a}}$ & $85^{\mathrm{a}}$ & $75^{\mathrm{ab}}$ & $89^{\mathrm{a}}$ & $57^{\mathrm{b}}$ \\
\hline 8 & 0 & $70^{\mathrm{cd}}$ & $84^{\mathrm{b}}$ & $73^{\mathrm{b}}$ & $78^{\mathrm{ab}}$ & $58^{\mathrm{d}}$ & $68^{\mathrm{a}}$ \\
\hline 8 & 8 & $68^{\mathrm{d}}$ & $84^{\mathrm{b}}$ & $71^{\mathrm{b}}$ & $80^{\mathrm{a}}$ & $68^{\mathrm{c}}$ & $57^{\mathrm{b}}$ \\
\hline
\end{tabular}

${ }^{\mathrm{a}}$ Means within a herbicide, location, and field combination followed by the same letter are not different at $P \leq 0.05$.

TABLE 4: Visible estimates of Italian ryegrass control by glyphosate and paraquat 4 weeks after application at the manufacturer's suggested weed size and 4 and 8 days after this weed size using spray solutions mixed the day of application or 4 or 8 days prior to application ${ }^{\mathrm{a}}$.

\begin{tabular}{lccc}
\hline $\begin{array}{l}\text { Timing of application after } \\
\text { optimum weed size }\end{array}$ & $\begin{array}{c}\text { Timing of solution preparation } \\
\text { prior to application }\end{array}$ & \multicolumn{2}{c}{$\begin{array}{c}\text { Italian ryegrass control } \\
\text { Plyphosate }\end{array}$} \\
\hline Days & Days & $87^{\mathrm{a}}$ & $95^{\mathrm{a}}$ \\
\hline 0 & 0 & $80^{\mathrm{bc}}$ & $83^{\mathrm{ab}}$ \\
4 & 0 & $73^{\mathrm{d}}$ & $94^{\mathrm{a}}$ \\
4 & 4 & $77^{\mathrm{cd}}$ & $93^{\mathrm{a}}$ \\
8 & 0 & & 9 \\
\hline
\end{tabular}

${ }^{\mathrm{a}}$ Means within a herbicide followed by the same letter are not different at $P \leq 0.05$.

control by lactofen was influenced when left in spray solution for 4 or 8 days. At Rocky Mount, Palmer amaranth control was not reduced when left in spray solution for 4 or 8 days prior to application. At Falcon, lactofen solutions prepared 4 or 8 days prior to application increased Palmer amaranth control 10 and 11 percentage points, respectively, when comparing within application timings. Regardless of weed size or the interval between solution preparation and application, Palmer amaranth control by glyphosate and paraquat was $96 \%$ to $100 \%$ and $87 \%$ to $95 \%$, respectively (data not shown).

Italian ryegrass control by glyphosate was influenced by the combination of weed size and timing of solution preparation. Control did not differ when comparing within application timings but was generally lower when application was delayed (Table 4). Italian ryegrass control by paraquat was $91 \%$ to $95 \%$ regardless of application timing or mixing interval.

Percent reduction in common ragweed fresh weight by glufosinate, glyphosate, and lactofen was not influenced by the interaction of experiment and combination of weed size and timing of solution preparation. However, percent reduction in broadleaf signalgrass fresh weight was affected by the combination of mixing interval and weed size. Broadleaf signalgrass fresh weight reduction was $86 \%$ to $89 \%$ when clethodim was applied at the optimum timing or 4 days past the optimum weed size (Table 5). However, fresh weight reduction decreased 16 to 27 percentage points when clethodim was applied 8 days past the optimum weed size for control. Percent fresh weight reduction of Palmer amaranth by 2,4-D, atrazine, dicamba, glufosinate, glyphosate, imazethapyr, lactofen, and paraquat was not influenced by either the experiment, timing of spray solution preparation, or weed size (Table 6).

Although delaying applications of herbicide solution may not decrease weed control, these data suggest sporadic changes in herbicide efficacy can occur when spray solutions remain in the tank for extended periods of time. A complete weed control failure across all experiments and all weed species did not occur when herbicide remained in spray solution for an extended period of time. Stewart et al. [18] also reported sporadic differences in weed control when herbicide solutions were prepared at various intervals prior to application, and there was no complete weed control failure in their research even though reductions in weed control were noted. Additionally, experiments were conducted using plastic spray bottles allowing adequate agitation to restore spray solutions immediately prior to application. Herbicide spray solution left in commercial spray equipment for an extended period of time will require vigorous agitation to ensure herbicide returns to solution. Farmers and commercial applicators 
TABLE 5: Percent reduction in fresh weight of common ragweed following glufosinate, glyphosate, and lactofen and percent reduction in fresh weight of broadleaf signalgrass following clethodim 4 weeks after application at the manufacturer's suggested weed size and 4 and 8 days after this weed size using spray solutions mixed the day of application or 4 or 8 days prior to application ${ }^{\mathrm{a}}$.

\begin{tabular}{|c|c|c|c|c|c|}
\hline \multirow{3}{*}{$\begin{array}{l}\text { Timing of application after } \\
\text { optimum weed size }\end{array}$} & \multirow{3}{*}{$\begin{array}{l}\text { Timing of solution } \\
\text { preparation prior to } \\
\text { application }\end{array}$} & \multicolumn{4}{|c|}{ Percent reduction in fresh weight } \\
\hline & & \multicolumn{3}{|c|}{ Common ragweed } & \multirow{2}{*}{$\begin{array}{c}\text { Broadleaf signalgrass } \\
\text { Clethodim }\end{array}$} \\
\hline & & Glufosinate & Glyphosate & Lactofen & \\
\hline Days & Days & & & $\%$ & \\
\hline 0 & 0 & $96^{\mathrm{a}}$ & $85^{\mathrm{a}}$ & $93^{\mathrm{a}}$ & $89^{\mathrm{a}}$ \\
\hline 4 & 0 & $98^{\mathrm{a}}$ & $79^{\mathrm{a}}$ & $86^{\mathrm{a}}$ & $86^{\mathrm{a}}$ \\
\hline 4 & 4 & $81^{\mathrm{a}}$ & $85^{\mathrm{a}}$ & $88^{\mathrm{a}}$ & $88^{\mathrm{a}}$ \\
\hline 8 & 0 & $97^{\mathrm{a}}$ & $74^{\mathrm{a}}$ & $88^{\mathrm{a}}$ & $62^{\mathrm{b}}$ \\
\hline 8 & 8 & $100^{\mathrm{a}}$ & $81^{\mathrm{a}}$ & $92^{\mathrm{a}}$ & $73^{\mathrm{b}}$ \\
\hline
\end{tabular}

${ }^{\mathrm{a}}$ Means within a weed species and herbicide column followed by the same letter are not different at $P \leq 0.05$.

TABLE 6: Palmer amaranth fresh weight reduction by 2,4-D, atrazine, dicamba, glufosinate, glyphosate, imazethapyr, lactofen, and paraquat 4 weeks after the manufacturer's suggested weed size and 4 and 8 days after this weed size using spray solutions mixed the day of application or 4 or 8 days prior to application ${ }^{\mathrm{a}}$.

\begin{tabular}{|c|c|c|c|c|c|c|c|c|c|}
\hline & & & & Paln & ner amaranth & fresh weigh & t reduction & & \\
\hline & application & $2,4-\mathrm{D}$ & Atrazine & Dicamba & Glufosinate & Glyphosate & Imazethapyr & Lactofen & Paraquat \\
\hline Days & Days & & & & & $\%$ & & & \\
\hline 0 & 0 & $55^{\mathrm{a}}$ & $72^{\mathrm{a}}$ & $97^{\mathrm{a}}$ & $96^{\mathrm{a}}$ & $85^{\mathrm{a}}$ & $27^{\mathrm{a}}$ & $93^{\mathrm{a}}$ & $62^{\mathrm{a}}$ \\
\hline 4 & 0 & $55^{\mathrm{a}}$ & $72^{\mathrm{a}}$ & $55^{\mathrm{a}}$ & $98^{\mathrm{a}}$ & $79^{\mathrm{a}}$ & $40^{\mathrm{a}}$ & $86^{\mathrm{a}}$ & $73^{\mathrm{a}}$ \\
\hline 4 & 4 & $50^{\mathrm{a}}$ & $63^{\mathrm{a}}$ & $34^{\mathrm{a}}$ & $81^{\mathrm{a}}$ & $85^{\mathrm{a}}$ & $14^{\mathrm{a}}$ & $88^{\mathrm{a}}$ & $82^{\mathrm{a}}$ \\
\hline 8 & 0 & $59^{\mathrm{a}}$ & $60^{\mathrm{a}}$ & $72^{\mathrm{a}}$ & $97^{\mathrm{a}}$ & $74^{\mathrm{a}}$ & $8^{\mathrm{a}}$ & $88^{\mathrm{a}}$ & $56^{\mathrm{a}}$ \\
\hline 8 & 8 & $50^{\mathrm{a}}$ & $47^{\mathrm{a}}$ & $37^{\mathrm{a}}$ & $100^{\mathrm{a}}$ & $81^{\mathrm{a}}$ & $19^{\mathrm{a}}$ & $92^{\mathrm{a}}$ & $78^{\mathrm{a}}$ \\
\hline
\end{tabular}

${ }^{\mathrm{a}}$ Means within a herbicide followed by the same letter are not different at $P \leq 0.05$.

may not have the capability to return herbicide completely into solution after remaining in the spray tank for extended periods of time.

Delayed application of postemergence herbicides will lead to increased growth and size of weeds, often making them more difficult to control. In postemergence herbicide experiments, a delay in application of 4 days did not result in a reduction in weed control even though weeds were on average $10 \mathrm{~cm}$ taller when herbicides were applied compared with application timing based on manufacturer recommendations. However, a delay of 8 days resulted in a general increase in weed height of approximately $20 \mathrm{~cm}$ over the time interval beginning at optimum application timing and resulted in less weed control in many instances. Other research [19-21, 24, 34, 35] has demonstrated that delaying application of herbicides used in this experiment can result in less control compared with application to smaller weeds. These experiments were conducted using a municipality water source with $\mathrm{pH} 6.7$ and relatively low water hardness. Results may have differed considerably if a different source of water was used $[2,5]$.

\section{Conflict of Interests}

None of the authors has a conflict of interests in terms of the products mentioned in the paper.

\section{Acknowledgments}

The North Carolina Peanut Growers Association, Philip Morris USA, and the Monsanto Co. provided partial financial support for this research. Appreciation is expressed to the staff at the Central Crops Research Station, Peanut Belt Research Station, and Upper Coastal Plain Research Station for technical assistance.

\section{References}

[1] Anonymous, "United State Geological Survey-National Water Quality Assessment Program," 2010, http://water.usgs.gov/ nawqa/studies/domestic_wells/hardness.html.

[2] D. D. Buhler and O. C. Burnside, "Effect of water quality, carrier volume, and acid on glyphosate phytotoxicity," Weed Science, vol. 31, no. 2, pp. 163-169, 1983.

[3] J. D. Nalewaja, F. A. Manthey, and R. Anyska, "Sodium bicarbonate antagonism of sethoxydim," Weed Technology, vol. 3, no. 4, pp. 654-658, 1989.

[4] J. D. Nalewaja and R. Matysiak, "Spray carrier salts affect herbicide toxicity to kochia (Kochia scoparia)," Weed Technology, vol. 7, no. 1, pp. 154-158, 1993.

[5] P. W. Stahlman and W. M. Phillips, "Effects of water quality and spray volume on glyphosate phytotoxicity," Weed Science, vol. 27, no. 1, pp. 38-41, 1979. 
[6] K. D. Thelen, E. P. Jackson, and D. Penner, "The basis for the hard-water antagonism of glyphosphate activity," Weed Science, vol. 43, no. 4, pp. 541-548, 1995.

[7] C.-H. Lin, R. N. Lerch, H. E. Garrett, and M. F. George, "Degradation of Isoxaflutole (Balance) Herbicide by Hypochlorite in Tap Water," Journal of Agricultural and Food Chemistry, vol. 51, no. 27, pp. 8011-8014, 2003.

[8] J. D. Nalewaja, R. Matysiak, and E. Szelezniak, "Sethoxydim response to spray carrier chemical properties and environment," Weed Technology, vol. 8, no. 3, pp. 591-597, 1994.

[9] D. Penner, D. Pratt, and J. J. Kells, "Substitutes for ammonium sulfate as additives with glyphosate and glufosinate," Weed Technology, vol. 17, no. 3, pp. 576-581, 2003.

[10] J. D. Nalewaja and R. Matysiak, "Influence of diammonium sulfate and other salts on glyphosate phytotoxicity," Pesticide Science, vol. 38, no. 2-3, pp. 77-84, 1993.

[11] K. D. Thelen, E. P. Jackson, and D. Penner, "The basis for the hard-water antagonism of glyphosphate activity," Weed Science, vol. 43, no. 4, pp. 541-548, 1995.

[12] A. M. Blair, "The addition of ammonium salts or a phosphate ester to herbicides to control Agropyron repens (L) Beauv," Weed Research, vol. 15, no. 2, pp. 101-105, 1975.

[13] G. J. Hall, C. A. Hart, and C. A. Jones, "Plants as sources of cations antagonistic to glyphosate activity," Pest Management, vol. 56, no. 4, pp. 351-358, 2000.

[14] R.-D. Xue, W. A. Qualls, H. Zhong, and C. L. Brock, "Permethrin decomposition after four month storage in the spray truck tanks during mosquito off season," Journal of the American Mosquito Control Association, vol. 24, no. 1, pp. 127-129, 2008.

[15] P. M. Eure, D. L. Jordan, J. S. Bacheler, A. C. York, L. R. Fisher, and R. Wells, "Agronomy and soils: performance of cotton agrochemicals when spray solution application is delayed," Journal of Cotton Science, vol. 15, no. 3, pp. 215-223, 2011.

[16] P. M. Eure, D. L. Jordan, G. S. Chahal et al., "Evaluation of pesticide efficacy in situation where spray application is delayed," Proceedings American Peanut Research and Education Society, vol. 42, pp. 60-61, 2010.

[17] P. M. Eure, L. R. Fisher, A. M. Stewart, and D. L. Jordan, "Evaluation of growth regulators and ripening agent used in fluecured tobacco when spray-solution application is delayed," Tobacco Science, vol. 49, pp. 21-24, 2012.

[18] C. L. Stewart, R. E. Nurse, M. Cowbrough, and P. H. Sikkema, "How long can a herbicide remain in the spray tank without losing efficacy?” Crop Protection, vol. 28, no. 12, pp. 1086-1090, 2009.

[19] G. O. Kegode and B. E. Fronning, “Artemisia biennis (biennial wormwood) control is influenced by plant size and weed flora at time of herbicide application," Crop Protection, vol. 24, no. 10, pp. 915-920, 2005.

[20] D. L. Jordan, A. C. York, J. L. Griffin, P. A. Clay, P. R. Vidrine, and D. B. Reynolds, "Influence of application variables on efficacy of glyphosate," Weed Technology, vol. 11, no. 2, pp. 354-362, 1997.

[21] R. M. Edmund, Jr, and A. C. York, "Factors affecting postemergence control of sicklepod with imazaquin and DPX-F6025: spray volume, growth stage, and soil-applied alachlor and vernolate," Weed Science, vol. 35, no. 2, pp. 216-223, 1987.

[22] J. E. Chafin, A. S. Culpepper, and L. B. Braxton, "Palmer amaranth, benghal dayflower, carpetweed, pitted morningglory, and broadleaf signalgrass response to glufosinate applied alone or mixed with 2, 4-D or dicamba," in Proceeding of the Beltwide Cotton Conference: Cotton Weed Science Research Conference, pp. 1551-1552, 2010.
[23] A. S. Culpepper, A. C. York, P. Roberts, and J. R. Whitaker, "Weed control and crop response to glufosinate applied to'PHY 485 WRF' cotton," Weed Technology, vol. 23, no. 3, pp. 356-362, 2009.

[24] B. A. Sellers, J. A. Ferrell, G. E. MacDonald, and W. N. Kline, "Dogfennel (Eupatorium capillifolium) size at application affects herbicide efficacy," Weed Technology, vol. 23, no. 2, pp. 247-250, 2009.

[25] R. Frans, R. Ralbert, D. Marx, and H. Crowley, "Experimental design and techniques for measuring and analyzing plant responses to weed control practices," in Research Methods in Weed Science, N. D. Camper, Ed., pp. 37-38, Southern Weed Science Society, 3rd edition, 1986.

[26] T. C. Mueller and L. E. Steckel, "Efficacy and dissipation of pyroxasulfone and three chloroacetamides in a tennessee field soil," Weed Science, vol. 59, no. 4, pp. 574-579, 2011.

[27] S. B. Clewis, W. J. Everman, D. L. Jordan, and J. W. Wilcut, "Weed management in North Carolina peanuts (Arachis hypogaea) with S-metolachlor, diclosulam, flumioxazin, and sulfentrazone systems," Weed Technology, vol. 21, no. 3, pp. 629-635, 2007.

[28] C. L. Main, J. T. Ducar, E. B. Whitty, and G. E. Macdonald, "Weed management in southeastern peanut with diclosulam and flumioxazin," Weed Technology, vol. 19, no. 4, pp. 870-874, 2005.

[29] R. J. Richardson, H. P. Wilson, and T. E. Hines, "Preemergence herbicides followed by trifloxysulfuron postemergence in cotton," Weed Technology, vol. 21, no. 1, pp. 1-6, 2007.

[30] S. D. Askew, J. W. Wilcut, and J. Cranmer, "Cotton (Gossypium hirsutum) and weed response to flumioxazin applied preplant and postemergence directed," Weed Technology, vol. 16, no. 1, pp. 184-190, 2002.

[31] S. L. Meyers, K. M. Jennings, J. R. Schultheis, and D. W. Monks, "Evaluation of flumioxazin and S-metolachlor rate and timing for palmer amaranth (Amaranthus palmeri) control in sweetpotato," Weed Technology, vol. 24, no. 4, pp. 495-503, 2010.

[32] J. R. Whitaker, A. C. York, D. L. Jordan, and A. S. Culpepper, "Palmer amaranth (Amaranthus palmeri) control in soybean with glyphosate and conventional herbicide systems," Weed Technology, vol. 24, no. 4, pp. 403-410, 2010.

[33] N. R. Burgos and R. E. Talbert, "Weed control by spring cover crops and imazethapyr in no-till southern pea (Vigna unguiculata)," Weed Technology, vol. 10, no. 4, pp. 893-899, 1996.

[34] G. J. Steckel, L. M. Wax, F. W. Simmons, and W. H. Phillips II, "Glufosinate efficacy on annual weeds is influenced by rate and growth stage," Weed Technology, vol. 11, no. 3, pp. 484-488, 1997.

[35] C. A. King and L. R. Oliver, "Application rate and timing of acifluorfen, bentazon, chlorimuron, and imazaquin," Weed Technology, vol. 6, no. 3, pp. 526-534, 1992.

[36] E. Coetzer, K. Al-Khatib, and T. M. Loughin, "Glufosinate efficacy, absorption, and translocation in amaranth as affected by relative humidity and temperature," Weed Science, vol. 49, no. 1, pp. 8-13, 2001.

[37] D. M. Anderson, C. J. Swanton, J. C. Hall, and B. G. Mersey, "The influence of temperature and relative humidity on the efficacy of glufosinate-ammonium," Weed Research, vol. 33, no. 2, pp. 139147, 1993.

[38] J. D. Nalewaja and Z. Woznica, "Environment and chlorsulfuron phytotoxicity," Weed Science, vol. 33, no. 3, pp. 395-399, 1985. 


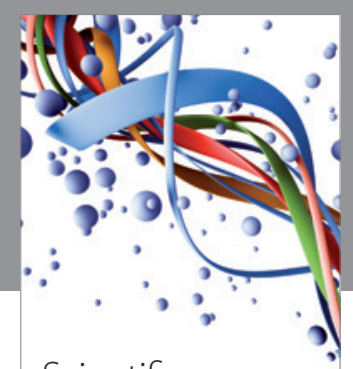

Scientifica
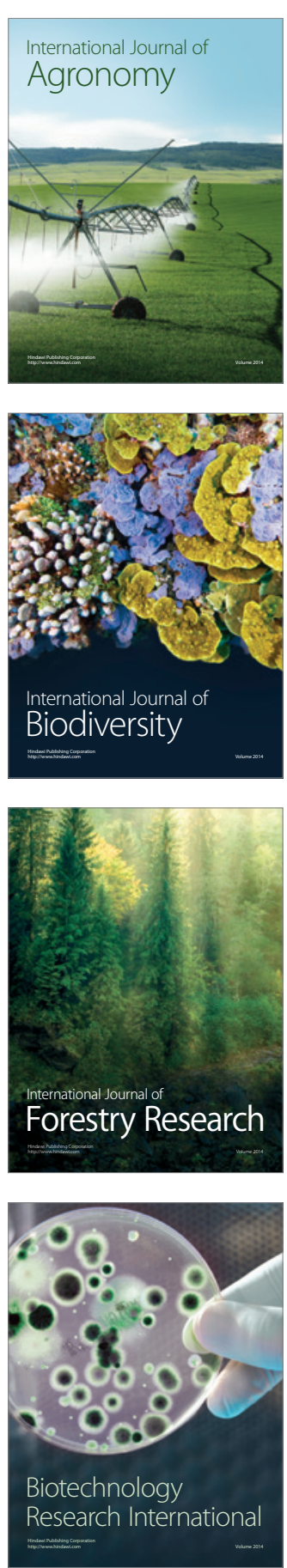
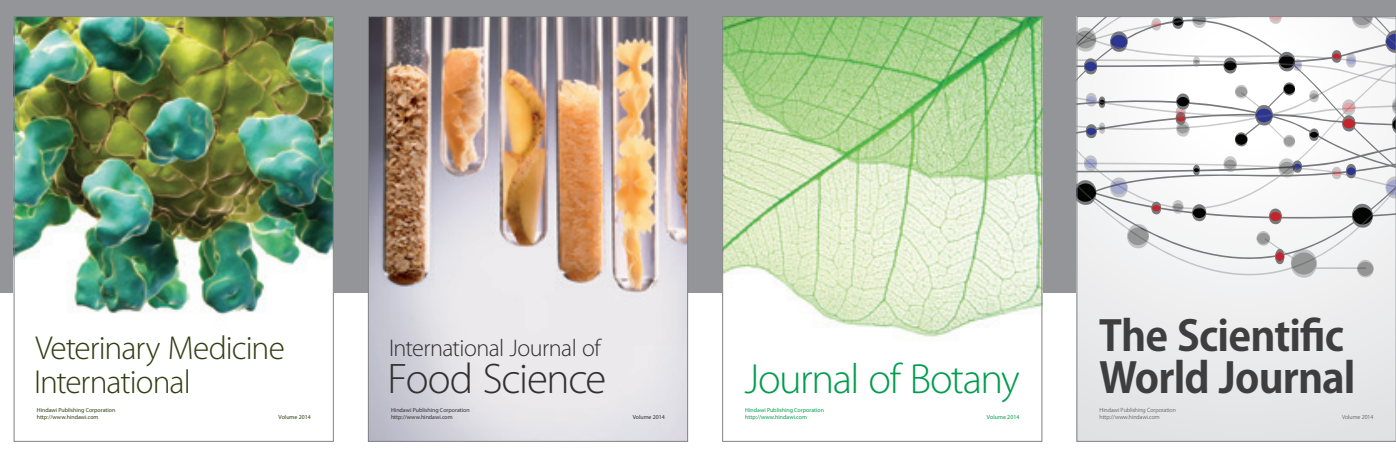

The Scientific World Journal
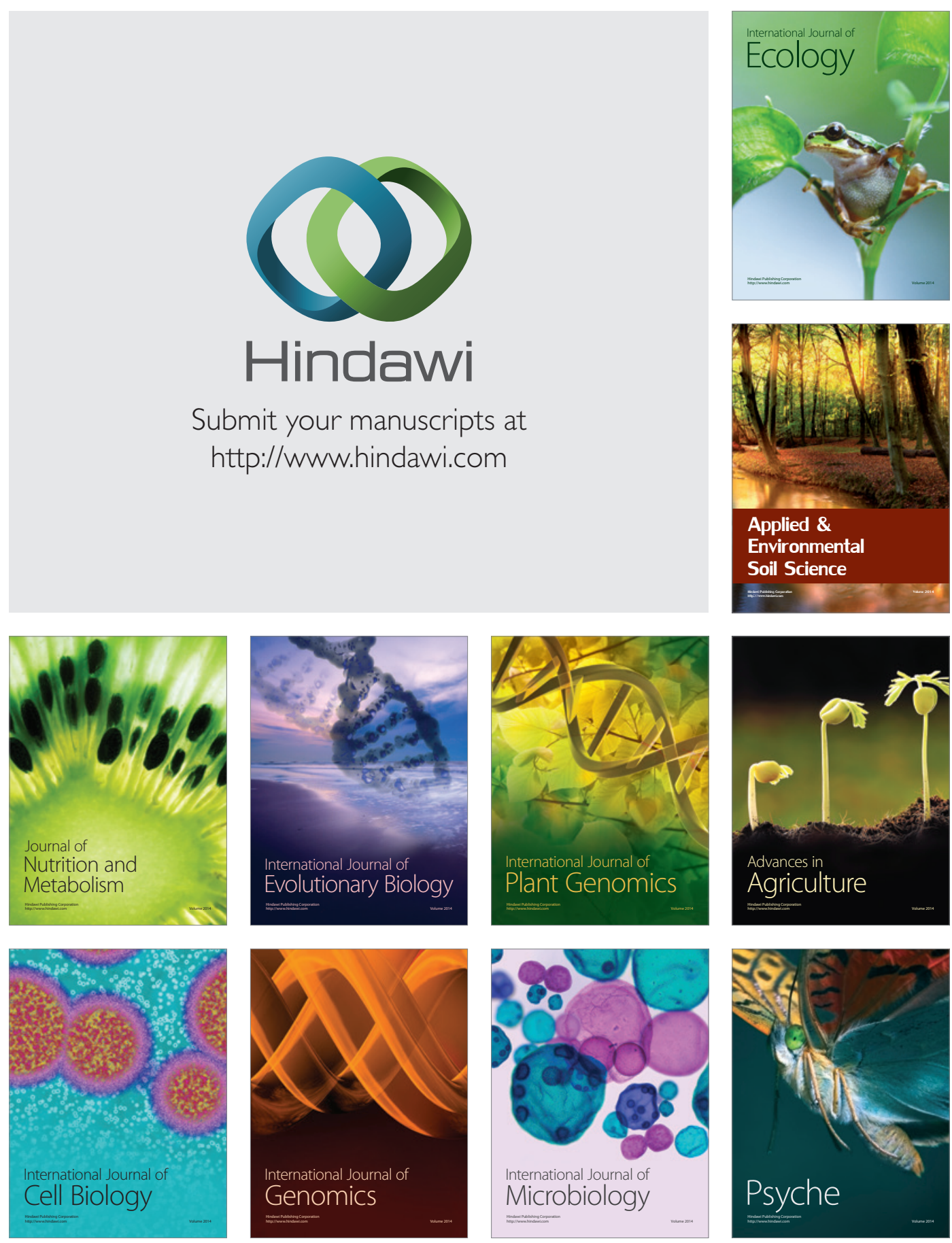